See discussions, stats, and author profiles for this publication at: https://www.researchgate.net/publication/259528220

\title{
Epistemic Forms of Integrated Water Resources Management: Towards Knowledge Versatility
}

Article in Policy Sciences · June 2013

Dol: 10.1007/s11077-013-9193-y

\section{CITATIONS}

24

2 authors:

Farhad Mukhtarov

Erasmus University Rotterdam

37 PUBLICATIONS 332 CITATIONS

SEE PROFILE
READS

259

Andrea Gerlak

The University of Arizona

112 PUBLICATIONS 1,484 CITATIONS

SEE PROFILE

Some of the authors of this publication are also working on these related projects:

Project Urban Water Governance View project

Project Global Discourses and Governance View project 


\section{Epistemic forms of integrated water}

resources management: towards knowledge versatility

\section{Farhad Mukhtarov \& Andrea K. Gerlak}

\section{Policy Sciences}

Integrating Knowledge and Practice to Advance Human Dignity

ISSN 0032-2687

Policy Sci

DOI 10.1007/s11077-013-9193-y

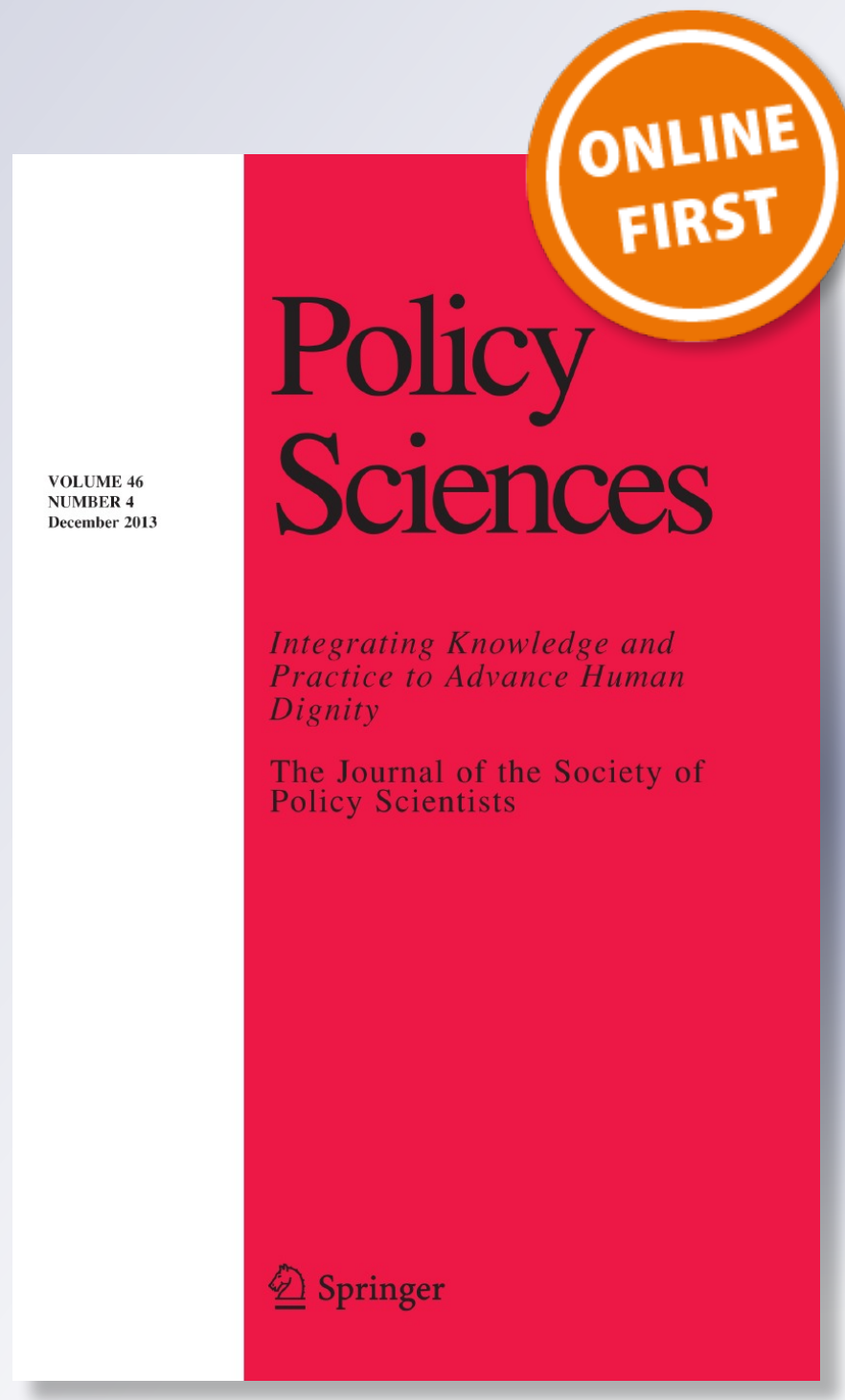

Springer 
Your article is protected by copyright and all rights are held exclusively by Springer Science +Business Media New York. This e-offprint is for personal use only and shall not be selfarchived in electronic repositories. If you wish to self-archive your article, please use the accepted manuscript version for posting on your own website. You may further deposit the accepted manuscript version in any repository, provided it is only made publicly available 12 months after official publication or later and provided acknowledgement is given to the original source of publication and a link is inserted to the published article on Springer's website. The link must be accompanied by the following text: "The final publication is available at link.springer.com". 


\title{
Epistemic forms of integrated water resources management: towards knowledge versatility
}

\author{
Farhad Mukhtarov • Andrea K. Gerlak
}

(C) Springer Science+Business Media New York 2013

\begin{abstract}
In the past two decades, integrated water resources management (IWRM) has come to represent a dominant policy narrative in the field of water policy and governance. However, IWRM has come under strong criticism in recent years for what critics see as a poor record of implementation and heavy emphasis on technocratic solutions. We outline how the present debate around IWRM has become narrowly construed by focusing exclusively on IWRM as an analytical and prescriptive concept. We argue that this narrow conceptualization of IWRM, or the prescriptive epistemic form, which sets forth a set of guidelines for implementation in accordance with the logic of instrumentality, has in part resulted in a stalemate manifested in less research on the subject and scarcer attention of policy makers. To help advance beyond the stalemate, we propose two additional epistemic forms: discursive, as a point of reference for the discussion of power and values in water management and practical, or experiential and context-based understanding of water management. Recognizing this diversity of epistemic forms of IWRM to include the discursive and practical can create a shared space for multiple conflicting epistemologies and allow ways of knowing of non-expert stakeholders, thereby lessening the polarized nature of the discourse. Our typology of three epistemic forms-prescriptive, discursive and practical - offers public policy scholars a heuristic tool to approach policy concepts from multiple dimensions. Recognizing multiple epistemic forms requires new skills from policy workers and analysts, as well as institutional arrangements for articulating and translating across these forms.
\end{abstract}

F. Mukhtarov (ه)

School of Public and International Affairs, Azerbaijan Diplomatic Academy, Baku, Azerbaijan e-mail: fmukhtarov@gmail.com; fmukhtarov@tudelft.nl

F. Mukhtarov

Department of Biotechnology, Delft University of Technology, Delft, The Netherlands

A. K. Gerlak

International Studies Association and Udall Center for Studies in Public Policy, University of Arizona, Tucson, AZ, USA

e-mail: agerlak@isanet.org 
Keywords Epistemology $\cdot$ IWRM $\cdot$ Policy discourse $\cdot$ Knowledge $\cdot$ Ways

of knowing

\section{Introduction}

Over the past two decades, integrated water resource management (IWRM) has come to dominate water resource management and policy discourse as a framework for holistic management of water and related bio-physical and socio-economic systems (GWP 2005; Watkins 2006; Saravanan et al. 2009; Engle et al. 2011; Tremblay 2011). IWRM features prominently in academic publications and also reports and initiatives of high-profile organizations, such as UNEP's Agenda 21, the UN World Summit on Sustainable Development in 2002 and other global events and publications (Conca 2006).

IWRM is promoted as an ideal approach to achieve efficient, equitable and sustainable development and management of the world's limited water resources (UN-Water 2008, 2012). Although more than thirty competing definitions of IWRM have emerged (Mukhtarov 2009), it is commonly seen as a process that 'promotes coordinated development and management of water, land and related resources, in order to maximize economic and social welfare in an equitable manner without compromising the sustainability of vital systems' (GWP/TAC 2000, 22).

The modern incarnation of IWRM can be traced to the 1992 Rio-de-Janeiro Earth Summit and the Dublin Statement on Water and Sustainable Development. It resulted in part as a reaction to the growing consensus that the sectorization and fragmentation of water management is at the core of the problems with water resources (ICWE 1992; UNEP 1994). The rise of IWRM can also be traced to a growing realization that the roots of the water crisis lie less in poor financing or technology failures than in 'poverty, inequality and unequal power relations, as well as flawed water management policies that exacerbate scarcity' (Watkins 2006, 1).

What distinguishes IWRM from previous efforts of water management is an emphasis on integration of various aspects of water management, such as water uses by sectors, multiple levels of governance, promotion of river basins as management units and greater participation of stakeholders in water management and decision-making process (Mukhtarov 2008). With the rise of IWRM, water management has shifted away from territoriality and towards neo-liberal approaches to management, such as a greater role of the private sector, pricing mechanisms and ecosystem valuation (Conca 2006; Mollinga et al. 2006).

Generally, proponents of IWRM argue for the necessity of integration across various users of water, for example industry and municipalities, and levels of governance in water management, such as local, regional and national (i.e. Mitchell 1997; GWP/TAC 2000; GWP 2004; Mitchell 2005; Engle et al. 2011). Yet, some opponents claim that such integration is doomed due to the inherently political processes at play (Biswas 2004; Biswas et al. 2005; Rahaman and Varis 2005; Jeffrey 2007; Petit and Baron 2009). Some research highlights failures associated with the implementation of IWRM, including Walther's (1987) study of IWRM implementation in Canada, where the outcomes of IWRM have been explained more by historical factors than institutional design (Medema 2006). The failure to replicate integrated river basin planning practiced in the TVA, Damodar and Jordan valleys further exemplifies how IWRM has failed in its 
comprehensive planning ambitions (Ekbladh 2002). A number of authors have therefore concluded that there is no sufficient reported evidence to support successful implementation of IWRM (e.g. Medema et al. 2008; Jeffrey and Gearey 2006; Biswas 2004, 2008).

Presently, the debate around IWRM has reached a stalemate in which the views are polarized and further conceptual elaboration has stopped (Saravanan et al. 2009; Engle et al. 2011; Tremblay 2011; Baumgartner and Pahl-Wostl 2013). The polarization of views is evident in the debate on the value of IWRM as a policy concept. The proponents, such as Mitchell (2005) and White (1998), argued for the necessity to move towards integration and coordination in water management, however long such process may take. Donors continue to promote and request IWRM definitions, plans and monitoring procedures (Baumgartner and Pahl-Wostl 2013, 3). The opponents, in turn, took a radically opposite view, arguing that beliefs in integration are 'idealistic' (Walther 1987). Others warn that successful integration is impossible due to the inevitable politics involved (Saravanan et al. 2009) and IWRM has become merely a policy 'buzzword' (Biswas 2004, 2008). A sign of the stalemate can be seen in fewer conceptual pieces written on IWRM and the fact that international water policy community has shifted towards new policy concepts such as 'water security' and 'water-energy-food' nexus (Cook and Bakker 2012). This shift away from IWRM and towards new policy concepts may well be justified by the purported failures of implementation. Yet, new policy concepts will likely face the same fate as IWRM if there is not a fundamental change in how problems are identified and understood, and policy solutions are designed.

In this paper, we call to move beyond narrow views of policy concepts to uncover the underlying epistemic forms through which such concepts can be seen in fuller light. Our goal is to propose a framework of three epistemic forms-prescriptive, discursive and practical - through which policy concepts come to be known. These forms represent stable meta-types of epistemologies, which address questions of knowledge and justification. They demonstrate how evaluations of policy concepts may occur and what makes a sound policy argument in the light of new demands of multiple epistemologies at play. We apply our epistemic forms framework to IWRM-a well-established and powerful policy concept that has dominated water resources management over the last two decades.

In our analysis of IWRM, we find that the resulting stalemate originates from narrow views of it as a universal, abstract and prescriptive concept to achieve predefined objectives of water management through rigorous planning at national or higher levels. This limited framing of IWRM does injustice to the complexities of water management. It ignores politics and ethics, as well as the on-the-ground context in which IWRM is sought. By viewing IWRM exclusively in this narrow way, the debate has become limited to the questions of implementation or even 'implementability', as the ultimate possibility of implementing IWRM as envisioned by its proponents has been brought into question by its critics (Biswas 2004; Mitchell 2008; Saravanan et al. 2009; Agyenim and Gupta 2010). As a result of being locked in this debate over 'implementability', other aspects of IWRM have been ignored.

In addition to approaching IWRM as an abstract prescriptive concept, we argue that it is a discursive concept, or a point of reference for discussions of values, ethics and power in water, and a practical concept, in which the context of practicing water management gives rise to practical knowledge. By acknowledging the existence of multiple epistemic forms, it becomes possible to evaluate policy concepts like IWRM from multiple dimensions. This can help to shift and expand the debate, allowing for less polarized discourse and a shared space for multiple conflicting epistemologies to come together and resolve conflict. 
This paper makes three important contributions to public policy research. First, our framework of multiple epistemic forms integrates several strands of literature, including discourse analysis, science and technology studies and public policy, to inform a simple yet eclectic framework to evaluate public policy concepts and construct policy arguments. As a heuristic tool, our typology of epistemic forms will contribute to students, practitioners and academics to approach policy concepts from multiple dimensions. Second, through application of our framework to IWRM, we illustrate how to approach policy concepts from multiple angles in order to inform policy and lead public debates away from polarization and closer to compromise. Third, our analysis reveals that recognizing multiple epistemic forms requires new skills from policy workers and analysts, as well as institutional arrangements for articulating and translating across these forms. We propose concrete measures devised to prepare policy makers for the world of epistemic pluralism, including versatility of knowledge and skilled intermediaries.

We begin by outlining how the current IWRM debate is locked in a stalemate. Next, we introduce our typology of three epistemic forms and sketch how this applies to IWRM. Then, we outline the implications for moving beyond the polarized debate and policy implications of such a broadened view of policy. Finally, we conclude by offering ways forward in engaging in a more productive, meaningful debate on and practice of IWRM.

\section{The contemporary IWRM debate: locked in a stalemate}

Despite its widespread popularity and prominence, IWRM has faced significant criticism in recent years (e.g. Biswas 2004; Brugnach and Ingram 2012a). Presently, there is debate around (1) the value of IWRM as a managerial concept, (2) the conceptual integrity of IWRM and (3) the relationship between IWRM and other concepts in natural resources management. Taken together, these three contemporary debates around IWRM demonstrate how IWRM has been narrowly construed as a prescriptive concept.

The debate on the value of IWRM as a managerial concept

The debate on the value of IWRM questions whether integration can be achieved in water resource management (Saravanan et al. 2009). Proponents of IWRM argue that its inclusiveness and the ability to bring together various stakeholders with different backgrounds are useful for facilitating a consensus. These scholars claim that one of the main benefits of using IWRM as a paradigm is its focus on the blending of viewpoints (Grigg 1999: cited in Medema et al. 2008). Some scholars refer to IWRM as a boundary object that connects sectors, disciplines and professions (Guston 2001; Jeffrey and Gearey 2006; Mollinga et al. 2006). Recent developments in the literature on IWRM have drawn on some strategies of adaptive management moving the discussion of how to integrate further on (Galaz 2007; Medema et al. 2008; Lenton and Muller 2009). Another important advantage of IWRM evoked by its proponents is that it allows for important issues to be brought into water discussions, such as the issues of water allocation, equity and sustainable development (Mollinga et al. 2006).

Yet, some research counters that the record of implementation of IWRM has been poor (Biswas 2004; Medema 2006). Authors suggest that due to its vagueness, IWRM has degenerated into a buzzword that is used by different actors with different understandings of its meaning and allowed for vested interests of consultants and various experts to take advantage of the concept's widely perceived universal applicability (Ingram 2013; 
Bouteligier 2011; Jochn-Clausen and Fugl 2001). Whilst the latest documents advocating IWRM acknowledge the importance of the context in tailoring of the concept to the local circumstances, some critics argue that IWRM is confusing, unnecessary and carries the seeds of centralization (Rahaman and Varis 2005). Others suggest that IWRM cannot be achieved through blueprints due to the primacy of politics, and instead, needs to be studied in particular context with explicit attention to the contingent policy process (Saravanan et al. 2009, 77).

The debate on conceptual integrity of IWRM

The second debate on conceptual integrity of IWRM is closely linked to the debate on its value as a managerial concept. Scholars point to the dozens of competing definitions, foci and conceptualizations of IWRM discussed in the literature (Mukhtarov 2009; Agyenim and Gupta 2012). Moreover, the amalgamation of ideas that go under the banner of IWRM is very broad ranging from the ideas of participation, decentralization, bio-regionalism to learning, experimentation as well as multi-level governance, cross-sectoral integration and equity (Mukhtarov 2009; Agyenim and Gupta 2012). When van Kerkhoff (2013) reviewed the use of the term 'integration' in natural resource management, she identified fifteen different uses of the term. Many of the definitions of meanings assigned to IWRM are often seen as incompatible and create an oxymoron. The comment below is illustrative of the main criticism of IWRM in this regard:

Despite its popularity (and one might say its reputation) IWRM remains: (i) a theory about, (ii) an argument for, and (iii) at best a set of principles... However, whilst IWRM reflects this post-modernist inspired agenda through its emphasis on contextual relevance, wider participation in planning and decision making, and responsive and reflexive practice, it remains rooted, by and large, in a 'predict and prepare' paradigm (Jeffrey and Gearey 2006, 4).

Thus, IWRM is seen as representing the traditional developmentalist concept in terms of its ambition to control water and related resources. On the other hand, IWRM calls explicit attention to stakeholder participation, adaptive management and contextual relevance. Conca (2006) highlights the in-built conflicts of IWRM, such as the tension between the concept's interventionist aspects, rooted in planning on the one hand, and the importance of liberalism and markets on the other. Some critics have concluded that IWRM is 'immature' as a management concept and needs further testing and development (Jeffrey and Gearey 2006). Jonker $(2002,719)$ has argued that '(t)here is still a long way to go to achieve a common understanding of IWRM and to develop and refine approaches for its successful implementation'. Others suggest that the ambiguities in IWRM are inherent and will not disappear with time; rather, it needs to be applied selectively (Mitchell 2008).

The debate on the links to other concepts in natural resource management

The third debate is about the relationship between IWRM and other concepts in natural resources management. IWRM has been discussed in relation to sustainable development (Conca 2006; Chene 2009), comprehensive rational planning (Biswas 2004), adaptive management and governance (Engle et al. 2011), strategic planning (GWP 2005; Mukhtarov 2009) and other concepts. Indeed, links between these concepts are not well defined, and often these are discussed inter-changeably. 
Increasingly, scholars argue that IWRM is especially akin to adaptive governance, or that the evolution of IWRM in the direction of adaptive governance is beneficial (Medema et al. 2008; Engle et al. 2011). Discussing IWRM together with the 'sister concept' of adaptive governance, Engle et al. $(2011,2)$ argue that the common goals of these two concepts are as follows: '(1) increase effectiveness through integration across social, ecological and hydrological systems; (2) add legitimacy and promote public acceptance through stakeholder participation, cooperation, decentralization and democratic decision making; (3) incorporate technical expertise through the inclusion of different forms of knowledge and promotion of social learning and (4) promote flexibility and adaptability through experimentation and learning in managing water resources'. All four of these stated goals have to do with improving the water resources situation on the ground and bear an instrumental value.

\section{A narrow view of IWRM}

All three fronts of the debate around IWRM construe it narrowly as a prescriptive concept, which is at the heart of the policy stalemate. In such a conception, knowledge of what IWRM is and how to implement it is based largely on scientific models from disciplines such as engineering, hydrology and organizational science. Such knowledge is largely independent of context. The strength of this epistemic form is in making examples of water management available to multiple actors as a learning ground. The danger, however, is to uncritically accept the models of 'good practice' of IWRM as successful in all context and indeed desirable for their own sake. Such models-like river basin planning-abound in the water policy world and are often linked to the IWRM framework (Mukhtarov and Gerlak 2013; Molle 2009). Furthermore, the prescriptive epistemic form of IWRM promotes a technocratic view of it with public participation agenda often being an add-on to projects (e.g. McCulloch 2009). Yet, this focus primarily on the prescriptive epistemic form of IWRM is reflected in the academic and policy debate about the 'implementability' of IWRM or the underlying logic that makes it instrumental. The debate can be enriched by epistemic pluralism and the introduction of values, norms and ethics, along with greater emphasis on context, policy learning and experimentation.

\section{Epistemic pluralism for public policy}

Policy scholars have long recognized the diversity of types of knowledge in policy processes, which include empirical-analytic knowledge and knowledge that is based on normative, personal and social interests (e.g. Fischer 1993, 1995; Renn et al. 1993; Weible et al. 2012). In the past decade, the concept of 'ways of knowing' has helped to further advance epistemic pluralism and invite scholars and policy workers to re-examine how they know in order to arrive at a particular policy decision.

In their research, Schneider and Ingram (2007) call attention to ways of knowing as a lens into understanding how meanings are produced and communicated in the policy process. For them, the ways of knowing approach examine how new narratives or constructions are arrived at through the interaction of different ways of knowing. Feldman et al. (2006) argue that perspectives on policy issues can be understood as fluid networks or 'ways of knowing'. They highlight how diverse ways of knowing provide opportunities for public managers to use inclusive practices associated with boundary experiences, objects and organizations to facilitate deliberation, and encourage the development of solutions 
based on new and hybrid policy issues. In contrast to the notion of 'policy' frames, which are maintained throughout a policy process, ways of knowing are dynamic and constantly in flux (Lejano and Ingram 2009, 655).

Viewing multiple ways of knowing from the policy advocacy perspective, Danish social theorist Bent Flyvbjerg (2001) excavates Aristotle's three ways of knowing or 'intellectual virtues'-episteme, techne and phronesis. 'Episteme...concerns universals and the production of knowledge, which is invariable in time and space, and which is achieved with the aid of analytical rationality. Episteme corresponds to the modern scientific ideal as expressed in natural science' (Flyvbjerg 2004, 359). Techne is practical-empirical knowledge that depends on the context and is always concrete and variable. Phronesis reflects the values and ethics involved in knowing and acting. It is the question of 'where are we going? Is this desirable? What should be done?' (Flyvbjerg 2001).

Building from this research, we provide a typology of three epistemic forms of public policy concepts: prescriptive corresponds to Aristotelian episteme; discursive corresponds to a broadened notion of phronesis and practical corresponds to techne. If multiple 'ways of knowing' suggest multiple perspectives on water which are highly dynamic and malleable and change with interactions in policy and social networks (Schneider and Ingram 2007; Ingram and Lejano 2009; Yanow 2009), our epistemic forms are relatively stable meta-types of three epistemologies. In our conception, 'ways of knowing' are derived from one or more 'epistemic form'. We see epistemology as 'the sub-discipline of philosophy devoted to questions of knowledge and justification' (Smith 1997, 132). For us, knowledge that is rational analytical is equally valid and influential in policy process as knowledge that is value based and power mediated as well as knowledge that emerges from deliberate and reflexive practice. Scientific knowledge should not be held superior to indigenous knowledge and worldviews (Barrett 2013). We emphasize the source of knowledge or 'knowing' or different epistemologies that guide policy makers and stakeholders and which need to be brought together for an effective and legitimate policy argument.

Ways of knowing suggest the existence of multiple types of knowledge claims that can be made by political adversaries in the policy process. For example, Ingram and Lejano $(2009,68-69)$ argue that water can be known as a product, in an environmental way, in a way that focuses on equity and sense of place, and in an economic sense, and that there is little interaction between these ways of knowing. These 'ways of knowing' can be linked to underlying epistemologies, which are important to articulate for demonstrating the incompleteness of each individual 'way of knowing'.

Our three epistemic forms represent a vehicle for how evaluations of policy concepts may occur and what makes a sound policy argument in the light of new demands of multiple epistemologies at play. These forms create a more 'pluralistic' space and thereby allow for a broader integration and richer evaluation. In the case of water, for example, we know that ' $(\mathrm{t})$ he worst errors in policy are made when one set of water values and one way of knowing dominate and exclude other ways. A mix is likely to be more sustainable and self-corrective in the long term' (Ingram 2013, 9). Figure 1 illustrates our three epistemic forms and how the space where all three forms meet marks sound policy argument and evaluation.

Epistemic pluralism, or the recognition of multiple equally legitimate epistemologies in public policy, has considerable implications for public policy. In the case of water policy, for example, multiple epistemologies underline the changing nature of policy work. Although water management practices have historically relied predominantly on expert knowledge and been more mono-sectorial in nature (Warner 2006, 18), there is growing recognition that policy arguments based on technical and analytical knowledge alone are 


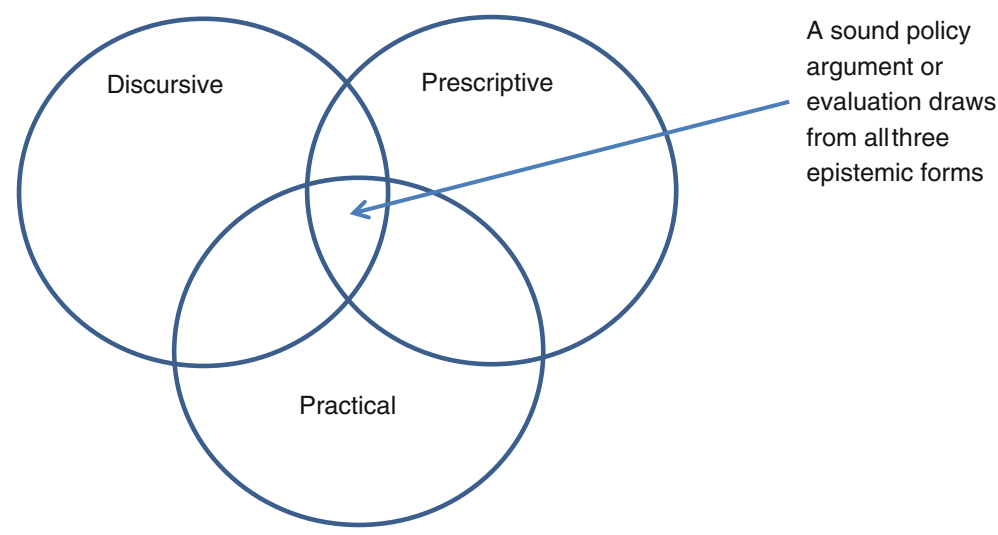

Fig. 1 Epistemic pluralism with prescriptive, discursive and practical epistemic forms of policies

insufficient (Tenbensel 2006). For instance, although suited with the rhetoric of 'sustainable human development' and 'water-based regional development' akin to the idea of IWRM, the emphasis on dam-building and irrigation development applied disproportionally in the Southeastern Anatolia Project (GAP in the Turkish abbreviation) has proven failure due to the grand design, lack of in-built learning in the policy process and the conflicts of values and meanings attached to water, land, ethnicity and culture in this part of Turkey (Mukhtarov 2009). The multiple values co-existing in the area not been recognized, and the strong power asymmetries and lack of policy experimentation and learning have all contributed to this failure (Mukhtarov 2012; Öktem 2005).

Management practices and decision making around the Colorado River's Glen Canyon Dam in the USA offer another illustration of how narrow meanings and epistemologies can result in policy failure. Although once heralded as a successful model of collaborative, adaptive regulation and management, Glen Canyon Dam's Adaptive Management Program is increasingly under fire. Some suggest that the program has been a significant factor in actually facilitating non-compliance with federally mandated endangered species regulations (Feller 2008). Others suggest that the program missed multiple opportunities to foster agency and stakeholder learning and to cultivate constructive engagement of stakeholders due to a failed institutional design and implementation (Susskind et al. 2010).

Another recent example from the water policy in the USA also makes a case for epistemic pluralism. In describing the role and power of narratives in a case involving the Los Angeles Department of Water and Power using reclaimed wastewater for drinking, Lejano and Leong $(2012,794)$ highlight the 'danger of relying solely on a single, simplistic interpretation'. In this case, despite the scientific evidence of safety and palatability of such water, citizen groups mobilized a publicity campaign against the initiative. In response, government and industry officials working on the program relied only on the arguments derived from the prescriptive epistemic form having assumed that public had little knowledge of the science behind water reuse. By not engaging with the values, myths and images invoked in narratives advanced by the citizen groups, engineers and politicians ignored the roots of public anxiety and eventually failed to proceed with the project.

The extent to which policy makers are guided by a single way of knowing or paradigm is debated (Wilder and Howlett 2013). Hall (1993) argues that policy makers are constrained by the paradigms within which they view policy problems and solutions, and 
policy change happens mostly with paradigm shifts. On the other hand, authors such as Levi-Strauss (1966) and Freeman (2007) suggested that social actors including policy makers are able to pick from various epistemologies and paradigms simultaneously.

In a study of how policy practitioners make sense of learning, Richard Freeman (2007) suggested the model of 'epistemological bricolage' in which policy practitioners routinely engage in mixing various 'epistemological frames' in their daily work, to an extent that this activity is unconscious. Such frames include 'the rational, scientific epistemology in which they are usually trained...the managerial resources and constraints with which they work, and the social and political ways of knowing that are the currency of their daily practice' (Freeman 2007, 490).

Our concept of epistemic pluralism builds upon the ideas of 'epistemological bricolage' by suggesting the three meta-types of epistemologies and arguing for a formalized, intentional and conscious process of their mixing in policy development. With epistemic pluralism, policy actors and coalitions make an explicit appeal to certain values. They also consider power relations that infuse policy space at a particular moment. Finally, epistemic pluralism accords the experiential knowledge that resonates with stakeholders. In this way, policy work becomes an exercise in the ability to be sensitive to multiple and interacting epistemic forms in order to mix analytical tools with dominant values, consider the power balance and rely on experiential knowledge. This requires policy actors to behave more like 'craftspeople' than engineers (Lach et al. 2005; Wagenaar 2004).

As outlined earlier, IWRM has been portrayed and legitimized largely in the prescriptive epistemic form with clearly defined problems and solutions, identifiable causeeffect relationships and the overall 'blue-print' or cookbook approach. To help move beyond the dominant, prescriptive approach, we next outline two alternative epistemic forms of IWRM: discursive and practical. In doing so, we provide a better understanding of the value and richness of epistemic pluralism in the context of IWRM. Specifically, we illustrate how a discursive way of knowing provides a lens into the issues of power, values and ethics, whilst the practical way of knowing offers insights into on-the-ground decision making and the importance of context.

\section{The discursive way of knowing IWRM}

Knowing IWRM as a discourse means being reflexive and explicit about the underlying values of water use and management, about the symbolic dimension of water in decisionmaking process and about the role of power in how meanings are constructed. Our notion of discursive way of knowing draws from the discussion of phronesis (Flyvbjerg 2001), discourse analysis (Hajer and Versteeg 2005) and ethics (e.g. Delli Priscoli 2012). A discourse can be defined as 'shared way of apprehending the world, enabling those who subscribe to it to put bits of information together in coherent accounts. The assumptions, the judgments and contentions on which each discourse rests, provide the basic terms for analyses and debates' (Dryzek 1997, 8).

This tradition of research discusses knowledge in the framework of power and claims that what we know and how we know is often constructed though power-mediated processes. For example, building dams for hydropower generation in the Southeastern Turkey has been framed by the Prime Minister Erdogan as bringing development and light to the society, whereas any attempt to oppose damming rivers may then be interpreted as conservatism and standing on the way of Turkey's development (Mukhtarov 2009). Seeing meaning as fluid and contingent upon power, values and the politics are at the heart of the 
discursive epistemic form of IWRM. Here, we can see how a combination of these elements gives rise to the IWRM knowledge.

Clearly articulating values behind water management, and bringing back the ethics of water is a subject of increasing attention of scholars (Gerlak et al. 2011; Feitelson 2012; Delli Priscoli 2012). Delli Priscoli $(2012,33)$ argues that if left unexamined, the value assumptions embedded in models of water institutions in humid areas could be disruptive for arid areas, whilst value assumptions embedded in the rich's prescriptions for the poor could be devastating to the prospects of the poor they seek to help'. Making such value assumptions explicit is not an easy task. The key question is what guides problem definition and what is seen as important and desirable in water management in a given society or community at a given time (Molle 2011). Universal moral imperatives may not hold in specific cases, and philosophers, such as Kant, Habermas and Foucault, among others, have discussed whether ethical principles are absolute that is relevant in all contexts, or relative, that is, change depending on the context (Flyvbjerg 2001).

The literature on IWRM has ignored this dimension of water management, and instead, Malin Falkenmark's concept of hydrosolidarity has become an embodiment of the 'ethics' in water discussions. Hydrosolidarity is defined as an 'all encompassing, multi-dimensional guiding ethic for solving water-related problems' (Falkenmark 2005, 40) and seen as a concept going beyond the 'management-oriented focus of IWRM, which is driven largely by technical and political considerations' (Gerlak et al. 2011, 252). The 'managementoriented focus' of IWRM invoked by Gerlak et al. (2011) and contrasted to hydrosolidarity is, in fact, the tension between the prescriptive way of knowing IWRM and the underrepresented discursive or phonetic dimension of IWRM. A good example of IWRM falling short to account for values and power is the human rights-based approach to water management that has developed as a separate discourse in the 2000s (Gerlak and Wilder 2012). Tremblay (2011), for example, claims that the human rights to water and IWRM represent different approaches that complement each other. He further states that any consideration of IWRM and human right to water approach needs to take place in the context of practice: 'The tensions between IWRM and the HRBA (human rights based approaches) must be resolved contextually by local water managers and stakeholders at the ground level. Generic answers to such issues would perpetuate the problems created by the inconsiderate transplant and imposition of alien models and narratives on social and environmental contexts to which they are not adapted' (Tremblay 2011, 356).

On the other hand, reliance on value positions for water management without proper consideration of what happens when such concepts hit the ground has also led to failures. A good example is the policy of water user associations (WUA) often placed in the literature on decentralization and IWRM (Kidd and Shaw 2007). With the 'subsidiarity principle' that responsibilities should be devolved to as lowest levels of governance as possible, WUAs have been justified on the grounds of promoting democratic decision making with less attention to the overall effects of such action and its practical impacts (e.g. Harris 2008). The tradition of institutionalism research has produced similar findings that the complex interaction on the ground often defies the most ingenious scientific designs and value predispositions (Bartley et al. 2008; Campbell 1998).

Another discursive aspect of IWRM is that it has become a symbol of modernity, progress and development. Increasingly, global water governance is discussed in connection with IWRM (Pahl-Wostl et al. 2008; Gupta 2010; Baumgartner and Pahl-Wostl 2013). This way of knowing IWRM acknowledges the value of IWRM for international expert and practitioner networks to build up, share and co-produce abstract IWRM knowledge. Careers, courses, trainings, conferences, publications and other aspects of what 
constitutes global water governance efforts all rotate around IWRM, and it is clearly a different type of logic that drives the popularity of IWRM than that of solely altering socioecological systems on the ground. According to international relations and water scholar Ken Conca (2006, 127 emphasis added), 'IWRM has become the discursive framework of international water policy-the reference point to which all other arguments end up appealing'.

The symbolic dimension of IWRM recognizes it as an artefact that may have life of its own. However, symbolic issues need to be analysed in their context. As Agranoff and Radin (1991) argue, 'without the context, which brings out symbolic issue, there is no explanation'. This emphasis on the link between the discursive and the context provides a helpful transition to our discussion of the practical way of knowing IWRM.

\section{The practical way of knowing IWRM}

Knowing IWRM as a practical concept means that there is no universal knowledge that would work in any context and that learning and experimenting is essential for desired policy change. Knowing IWRM through experience is different from knowing it through abstract models and guidelines (Scott 1998; Cook and Wagenaar 2012). Akin to the concept of 'metis' (Scott 1998), such knowledge is contextually bound, personal and often unarticulated or hard to articulate.

As Wenger $(1998,141)$ argues: 'every practice is in some sense a form of knowledge, and knowing is participating in that practice'. The importance of practice becomes greater with acknowledging it as a legitimate source of knowledge and not a mere 'empirical testground'. In this way, events and context become inseparable. A quote from Brugnach and Ingram $(2012 \mathrm{a}, 52)$ summarizes succinctly the form that IWRM takes as a practical concept:

Knowing-through-practice implies that knowledge is specific to a particular situation and, therefore, tied to specific communities. In this way, practice is not intended to reflect 'best practices' or more cookbook approaches. Rather, it is through interaction that people make sense of reality, negotiating the meaning they give to their surroundings and their actions. Knowing then involves the coordinated action among actors who engage in some form of collaboration.

Approaching IWRM from this perspective requires addressing framing issues and ambiguities, as well as creating opportunities for participation (Brugnach and Ingram 2012b). Effective translation across cultural, disciplinary and other backgrounds becomes essential. The collaborative frameworks, such as joint planning and joint experimentation, along with others, can facilitate a view of IWRM practice that is reflexive and emergent (Yanow 2009).

Recent research in policy implementation and 'practice' suggests that the process of transformation is substantive and that the knowledge that emerges from practice substantially differs from epistemic knowledge (Cook and Wagenaar 2012). The 'making-indoing' of IWRM is the essence of it as a practical concept. For example, knowledge that it usually takes much longer to build infrastructure than planned and that non-structural flood defence is partnership based, or that partnerships are culturally dependent emerges from practicing. In this way, practice is not just a conduit for knowledge but practice is a vital element of knowing in the world (Cook and Wagenaar 2012, 16).

As an illustration of practical way of knowing water management, Brugnach and Ingram (2012a) bring examples of contextual water governance from the Northwest 
Territories in Canada, where traditional knowledge system based on spiritual teaching is channelized into official decision-making process. In another recent study, Scott et al. (2012) highlight the role of science-policy networks in heightening the capacity of institutions to mitigate potential vulnerabilities via water management and disaster relief and prevention in the Arid Americas. In this context, communities of practice of stakeholders and scientists engage in a dialogue process that goes beyond traditional strategies that historically favour hydro-climatological sciences, infrastructures and technologies to address vulnerabilities and foster proactive, integrated responses to sustainable resource.

However, understanding the process of practice as a source of situated knowledge rather than the area in which generic knowledge is empirically applied is not the mainstream approach. The discussion of implementation deficits is not solely about the rational translation of policy from theory to practice but the emergence of policy from practice and the subsequent adjustment of theory to correspond to the knowledge derived from practice (Wagenaar and Cook 2003). Recent research on compliance with environmental and health standards in drinking water illustrates this point. In their study of enforcement and compliance with the European Commission Drinking Water Directive in Hungary, Leventon and Antypas (2012) find that although all actors involved in monitoring the levels of arsenic in water in Hungary are aware about the maximum limit of 50 parts per billion and the health risks associated with consuming water with higher arsenic concentrations, arsenic-contaminated water consumption through artesian wells still continues.

The practicing of policy making at local, regional and national levels makes the continuation of dangerous drinking water policy possible despite the European regulations and the Hungarian government's commitment to comply. This stems from the specific policy situation in Hungary and multiple rationales of actors in continuing consumption of contaminated water. Understanding the reasons behind the continued consumption of arsenicrich drinking water in Hungary therefore is only possible through studying in detail the policy practice and how multiple actors engage in policy-making process.

\section{The diversity of epistemic forms IWRM}

The three epistemic forms of IWRM, similar to policy concepts, differ from each other on a number of fronts. First, they differ in terms of their essence. A prescriptive way of knowing offers clear definitions of problems and solutions, good practices and mechanisms to integrate water and other resources across a number of dimensions (van Kerkhoff 2013). A discursive way of knowing provides more ambiguous and vague framework in which conflicting values come together and power is at play. A practical way of knowing, in turn, addresses collaborative interaction around construction of problems and solutions in situated and embedded contexts on the ground.

Second, the form of expression varies in the three epistemic forms. IWRM plans, legislation, participation guides, procedures and policy documents illustrate the prescriptive dimension. As a mode of analysis, the discursive dimension is illustrated by UN-Water reports, World Water Development reports (WWD), declarations, guidelines and donor projects. Finally, the practical dimension is expressed by participatory planning and joint planning approaches and highlighted in case studies and evaluation reports.

Finally, linked to the form of expression of IWRM through each of these epistemic lenses is the logic behind their use. In a prescriptive way of knowing IWRM, we can observe actors behaving in accordance with the 'logic of instrumentality' (Hall and Taylor 1996, 949), which sets itself the goal of defining the ends and the means of water management. In contrast, the discursive dimension makes the 'logic of social appropriateness 
Table 1 Prescriptive, discursive and practical epistemic forms of IWRM

\begin{tabular}{llll}
\hline & Prescriptive & Discursive & Practical \\
\hline Essence & $\begin{array}{l}\text { Clear definitions } \\
\text { of problems and } \\
\text { solutions } \\
\text { Prescription of action }\end{array}$ & Values and ethics & Contextual relevance \\
& Symbolism in policy & $\begin{array}{c}\text { Learning through } \\
\text { experimentation }\end{array}$ \\
Form of & IWRM plans & Power dynamics & Participatory planning \\
expression & Legislation, & UN-Water reports & Joint planning approach \\
& Participation guides & WWD reports & Declarations, guidelines \\
& Policy documents & Donor projects & Logation reports \\
Logic & Logic of instrumentality & Logic of appropriateness & Logic of concreteness \\
\hline
\end{tabular}

and inclusiveness' (Douglas 1986; Campbell 1998; Hall and Taylor 1996): more important as this is how the power is brokered and knowledge is produced across governance levels. Here, the choice of ends and means is as much a political project as a scientific one. In the practical sense, actors are more governed by the 'logic of concreteness' in gauging their abstract knowledge and goals against on-the-ground context.

Table 1 presents these differences between these three epistemic forms of IWRM as modes of analysis. These differences are by no means clear-cut and close links and overlaps exist among the forms. One epistemic form of IWRM may give rise to another. They complement each other without uncritically privileging any one of them.

\section{Beyond the stalemate, towards knowledge versatility}

The roots of the stalemate in the IWRM debate may be found in its limited epistemology manifested in the exclusive focus on IWRM as a prescriptive concept. Although the rationale for IWRM has been stressed in the letter and spirit of participation and inclusiveness, the debate has revolved around the issue of its effectiveness as a managerial concept and ultimate impact on the ground. This narrow focus on the effectiveness of IWRM in the logic of application of abstract system of knowledge to practice of water governance can be traced to Descartes. The Cartesian logic presents knowledge as 'certain, procedurally and analytically derived' and separable from practice, which in turn is the application of 'knowledge' (Cook and Wagenaar 2012, 5). This view of knowledge privileges abstract 'a priori' knowledge to that emerging from practice. The recognition of a qualitatively new type of knowledge that emerges from practicing IWRM conflicts with Cartesian logic, and is necessary to move beyond the present stalemate.

Revealing the diverging epistemologies as a source of this tensions is one key contribution of the framework. The epistemic forms framework allows us to more closely understand and penetrate the stalemate to reveal the tensions between the prescriptive and discursive dimensions of IWRM. Furthermore, the framework asserts that these tensions are inherent and need to be recognized and accepted as such. We argue that greater reflection and awareness of multiple ways of knowing in a policy setting, along with multiple epistemologies which underline these ways of knowing, would allow for better decision-making process. With the new analytic, we are shifting the focus away from 
implementation on other dimensions of IWRM. Our typology of epistemic forms framework provides a boundary space that allows multiple perspectives, values and ways of knowing to co-exist and be articulated for a decision maker. It also allows for joint implementation and experimentation as a result of practicing IWRM by a group of stakeholders. By moving away from the primary concern with implementation, we allow for less polarized discourse and a greater opportunity for a policy solution.

Epistemic pluralism is central to good policy making. A discursive way of knowing IWRM highlights both the ethics of water governance and the issue of values and power. The practical way of knowing calls attention to context and collaborative interaction among actors in networks that produces novel forms of knowledge. This is based on the claim that knowledge originates from practice, rather than knowledge gives rise to practice (Cook and Wagenaar 2012). These two forms - the discursive and practical—help to move beyond the dominant prescriptive approach. By grounding arguments around IWRM across all three epistemic forms, actors can engage in a broader debate and affect change more effectively. This versatility in types of knowledge makes for better policy arguments and represents a valuable political strategy for skilled policy actors who may strengthen their argument by making versatile knowledge claims (Tenbensel 2006, 202; Colebatch 2006). Further, the three epistemic forms provide a means of evaluating policy concepts to better determine whether and when they should be abandoned.

To effectively engage in epistemic pluralism, policy workers will need to learn how to tell compelling stories. Historically, water policy professionals and analysts have not been good storytellers, relying on the more 'bloodless' discourse of science and expertise (Ingram 2013, 9). But narratives may draw from multiple sources and forms of knowledge such as scientific evidence, values, normative maxims and personal experience of those engaging in water governance. They are our means of making sense of events, actors and ideas (Lejano et al. 2013). In this way, storytelling skills as policy advocacy may be a vehicle towards knowledge versatility and improved public policy.

One interesting means to develop appreciation of students of public policy and water management for power and uncertainty is the board game called SimsBethel, which makes the players confront the challenges of decision making when the needs of flood protection, recreation and drinking water supply are in conflict. This particular game is designed by a group of Dutch students based on the issues of the Bethel island and delta in California, but can be used to illustrate the typical issues of competing demands on water management (Hasman et al. 2013).

Another example is a recent innovative event at the Stockholm Water Week, the premier international gathering of water professionals from around the world, in September 2013 indicates a hopeful sign. Here, UNESCO-IHE and UN-Water created and performed a play on the current state of water resources within the International Year of Water Cooperation 2013. This demonstrates the use of drama beyond education and academic conferences, but also in communication and brainstorming with policy makers, industry and water professionals. The play, titled 'Theatre of the Absurd: Is there a Happy Ending to the Tragedy (of the Commons)?' (UN-Water 2013), represents an innovative way of engaging with the diverse values attached to water issues, power issues and appeals to the non-cognitive and non-analytical ways of our making sense of reality.

In addition to storytelling, water experts and scholars need new skills, tools and approaches to 'stitch' ways of knowing together and effectively make trade-offs between the multiple ways of knowing. This highlights the need for multi-analytic competencies in policy processes (Weible et al. 2012). In dealing with water-related challenges, such an approach requires the use of prescriptive and discursive knowledge yet, being open to 
alternative ways of framing and seeing issues that may emerge from practice. It likely requires an ability to see the whole system and its dynamics, to encourage integration of local knowledge and experimentation and the ability to identify emerging windows of opportunity (Westley et al. 2013). It is about being passionate to delve into the complexity of issues, yet being open to surprises (Yanow 2009). It also highlights the need for a good dose of humility and the cultivation of reflective practice (Yanow 2009).

Acknowledging that there will likely be many challenges to extending this notion of knowledge versatility beyond academic circles, we suggest that one path to achieve knowledge versatility may be to invite skilled intermediaries into the policy process, whose work is to translate between various ways of knowing, make them legible to various actors and communicate those effectively. The 'backward-mapping' approach to policy development (Elmore 1979), as well as various joint experimentation methods (Hornidge et al. 2009) and policy methods, including action research (Osseweijer 2006) and participatory assessments (Lemaire et al. 2010; Kaljonen et al. 2012), may also play important roles in promoting knowledge versatility around IWRM.

In addition to the development of new skills, new institutional arrangements will need to be devised, which will allow for equal representation of all three types of knowledge claims in policy development process. These arrangements may be characterized by intentional collaborative venues and processes to promote innovation and learning through regularized interactions and activities such as workshops and planning exercises (Gerlak and Heikkila 2011; Heikkila and Gerlak 2013; Goldstein and Butler 2011). Building the capacity for political deliberation that would allow opening up 'the possibility for an integration of interests in water policy management' will likely be a key institutional element for knowledge versatility (Brugnach and Ingram 2012b, 62).

A new form of intermediary may help ease the translation between various ways of knowing and facilitating a broader debate. The literature suggests that intermediaries have traditionally taken part in policy making, and have been described by scholars as 'strategic brokers', 'boundary spanners', 'interlocutors', 'border crossers', 'transactors' or 'cultural brokers' (Huitema and Meijerink 2009; Lendvai and Stubbs 2009). Often these are management or environmental consultants who are in the role of intermediaries and they possess a certain set of skills that allows them to be in between scales, discursive positions and disciplines. Consultants are often pushed to render their advice as technical and engage in de-politicization of processes. A new form of intermediaries for multiple ways of knowing will need go beyond such practices and derive legitimacy of knowledge claims not only from its technical status (Moss 2010), but also from the values such claims represent, their acceptability given the power balance, and their practical relevance. Such intermediaries may gradually establish the multiplicity of ways of knowing and multiple legitimacy of knowledge claims, thereby, setting a path for richer policy-oriented work.

\section{Conclusions}

Whether it is examination of its value as a managerial concept, its definitional and conceptual integrity or the relationship between IWRM and other concepts in natural resources management, IWRM has been consistently debated as a prescriptive concept. By viewing IWRM exclusively as a prescriptive concept, the debate has been reduced to the effectiveness of IWRM as a management tool. The root of the stalemate in the contemporary IWRM debate comes from the narrow focus on prescriptive aspects of IWRM and the failure to recognize multiple epistemic forms through which it can be viewed. 
Our typology of three epistemic forms - prescriptive, discursive and practical-helps to broaden the debate and arrive at policy arguments around IWRM based on a more complete view of the concept. But designing and analysing policies around IWRM require knowledge versatility. This speaks to the need for new skills of water policy actors, along with new institutional arrangements. Intermediaries may serve to assist in translating across and between multiple epistemic forms.

Knowledge versatility of water through storytelling may rehabilitate IWRM, make it more legitimate in water management and policy circles and fend off alternative concepts. Alternatively, it can prove that IWRM is unable to promote sustainable change and demands new alternative concepts to be complemented with or needs to be discarded altogether. Regardless of how this unfolds overtime, knowledge versatility represents a clearly articulated and substantiated transition away from technocratic and scientific view of water management represented by the Cartesian view, which privileges elite decision making based on expert knowledge. Ultimately, the shift towards decentralized, polycentric and diffused governance of water cannot be achieved with basing the detection of ends and selection of means through scientific methods only. It requires the discussion of multiple values, ways of knowing, multiple rationales based on power considerations and different meanings of what comes across as 'expertise' or evidence.

Yet, knowledge versatility raises significant governance questions. Future research is required to understand what skills can best enable policy actors to comprehend and translate between various epistemic forms, and the role of intermediaries in this process. The prospects of the debate or policy development that is based on versatility of knowledge do not make it necessarily equitable. Further research will be needed to better understand how resource availability and other actor characteristics shape the crafting and promotion of epistemic forms. At the practical level, in the context of water governance, training has so far privileged prescriptive approaches to water management, especially in engineering education establishments, and the shift to understand the discursive and practical elements will require new curricula, case studies and openness for interdisciplinarity.

\section{References}

Agranoff, R., \& Radin, B. A. (1991). The comparative case study approach in public administration. In J. L. Perry (Ed.), Research in public administration (Vol. I, pp. 203-231). Greenwich, CT: JAI Press.

Agyenim, J., \& Gupta, J. (2012). IWRM and developing countries: Implementation challenges in Ghana. Physics and Chemistry of the Earth, 47, 46-57.

Barrett, M. J. (2013). A hybrid space: enabling epistemological diversity in socio-ecological problemsolving. Policy Sciences, 46, 179-197.

Bartley, T., Andersson, K., Jagger, P., \& van Laerhoven, F. (2008). The Contribution of Institutional Theories to Explaining Decentralization of Natural Resource Governance. Society \& Natural Resources: An International Journal, 21(2), 160-174.

Baumgartner, T., \& Pahl-Wostl, C. (2013). UN-Water and its role in global water governance. Ecology and Society, 18(3), 3. doi:10.5751/ES-05564-180303.

Biswas, A. (2004). Integrated Water Resources Management: a Reassessment. Water International, 29(2), $248-256$.

Biswas, A. (2008). Integrated Water Resources Management: Is It Working? International Journal of Water Resources Development, 24(1), 5-22.

Biswas, A., Varis, O., \& Tortajada, C. (2005). Integrated water resources management in south and southeast Asia. New Delhi: Oxford University Press.

Bouteligier, S. (2011). Exploring the agency of global environmental consultancy firms in earth system governance. International Environmental Agreements: Politics, Law and Economics, 11, 43-61. 
Brugnach, M., \& Ingram, H. (2012a). Rethinking the Role of Humans in Water Management: Toward a New Model of Decision-Making. In B. R. Johnston (Ed.), Water, cultural diversity and environmental change: Emerging trends, sustainable futures? (pp. 49-64). Berlin, Germany: Springer.

Brugnach, M., \& Ingram, H. (2012b). Ambiguity: the challenge of knowing and deciding together. Environmental Science \& Policy, 15, 60-71.

Campbell, J. L. (1998). Institutional analysis and the role of ideas in political economy. Theory and Society, 27(3), 377-409.

Chene, J. (2009). Introduction: Integrated Water Resources Management: Theory versus practice. Natural Resources Forum, 33, 2-5.

Colebatch, H. (2006). What work makes policy? Policy Sciences, 39, 309-321.

Conca, K. (2006). Governing water: Contentious transnational politics and global institution building. Cambridge, MA: MIT Press.

Cook, C., \& Bakker, K. (2012). Water security: Debating an emerging paradigm. Global Environmental Change, 22(1), 94-102.

Cook, N., \& Wagenaar, H. (2012). Navigating the Eternally Unfolding Present: Toward an Epistemology of Practice. The American Review of Public Administration, 42(1), 3-38.

Delli Priscoli, J. (2012). Reflections on the nexus of politics, ethics, religion and contemporary water resources decisions. Water Policy, 14, 21-40.

Douglas, M. (1986). How Institutions think. Syracuse: Syracuse University Press.

Dryzek, J. S. (1997). The politics of the earth: Environmental discourses. Oxford: Oxford University Press.

Ekbladh, D. (2002). "Mr. TVA": Grass-roots development, David Lilienthal, and the rise and fall of the Tennessee Valley Authority as a symbol for U.S. Overseas Development, 1933-1973. Diplomatic History, 26(1), 335-374.

Elmore, R. (1979). Backward mapping: Implementation Research and Policy Decisions. Political Science Quarterly, 94(4), 601-616.

Engle, N., Johns, O., Lemos, M., \& Nelson, D. R. (2011). Integrated and adaptive management of water resources: Tensions, legacies, and the next best thing. Ecology and Society, 16(1), 19.

Falkenmark, M. (2005). Towards hydrosolidarity: Ample opportunities for human ingenuity. Stockholm: Stockholm Water Symposia.

Feitelson, E. (2012). What is water? A normative perspective. Water Policy, 14, 52-64.

Feldman, M., Khademian, A., \& Schneider, A. (2006). Ways of knowing and inclusive management practices. Public Administration Review, 66(s1) (December Supplement), 89-99.

Feller, J. M. (2008). Collaborative management of Glen Canyon Dam: The elevation of social engineering over law. 8 NEV. L.J. 896.

Fischer, F. (1993). Citizen participation and the democratization of policy expertise: From theoretical inquiry to practice. Policy Sciences, 26, 165-187.

Fischer, F. (1995). Evaluating public policy. Chicago: Nelson-Hall.

Flyvbjerg, B. (2001). Making social science matter. Cambridge: Cambridge University Press.

Flyvbjerg, B. (2004). Phronetic planning research: theoretical and methodological reflections. Planning Theory \& Practice, 5(3), 283-306.

Freeman, R. (2007). Epistemological Bricolage: How Practitioners Make Sense of Learning. Administration \& Society, 39, 476-496.

Galaz, V. (2007). Water governance, resilience and global environmental change-a reassessment of integrated water resources management (IWRM). Water Science and Technology, 56(4), 1-9.

Gerlak, A. K., \& Heikkila, T. (2011). Building a Theory of Learning in Collaboratives: Evidence from the Everglades Restoration Program. Journal of Public Administration Research and Theory, 21(4), 619-644.

Gerlak, A. K., Varady, R. G., Petite, O., \& Haverland, A. C. (2011). Hydrosolidarity and beyond: can ethics and equity find a place in today's water resource management? Water International, 36(3), 251-265.

Gerlak, A. K., \& Wilder, M. (2012). Exploring the Textured Landscape of Water Insecurity and the Human Right to Water. Environment: Science and Policy for Sustainable Development, 54(2), 4-17.

Global Water Partnership (GWP). (2000). IWRM toolbox. Retrieved 15 May, 2007, from http://www. gwpforum.org/servlet/PSP?chStartupName=_water. Stockholm: Global Water Partnership.

Global Water Partnership (GWP). (2004). IWRM plans and water efficiency plans by 2005: Why, what and how?. Stockholm: Global Water Partnership.

Global Water Partnership (GWP). (2005). Catalyzing change: A handbook for developing IWRM and water efficiency strategies. Stockholm: Global Water Partnership.

Global Water Partnership/Technical Advisory Committee (GWP/TAC). (2000). Integrated water resources management. Stockholm: Global Water Partnership. 
Goldstein, B. E., \& Butler, W. H. (2011). Collaborating for Transformative Resilience: Shared Identity in the US Fire Learning Network. In Bruce E. Goldstein (Ed.), Collaborative resilience: Moving from crisis to opportunity (pp. 339-358). Cambridge, MA: MIT Press.

Grigg, N. S. (1999). Integrated Water Resources Management: Who Should Lead, Who Should Pay? Journal of American Water Resources Association, 35(3), 527-534.

Gupta, J. (2010). Driving forces in global freshwater governance. In D. Huitema \& S. Meijerink (Eds.), Water policy entrepreneurs: A research companion to water transitions around the globe (pp. 37-61). Cheltenham: Edward Elgar.

Guston, D. H. (2001). Boundary Organizations in Environmental Policy and Science: An Introduction. Science, Technology and Human Values, 26, 399-408.

Hajer, M. (1995). The politics of environmental discourse: Ecological modernization and the policy process. Oxford: Oxford University Press.

Hajer, M., \& Versteeg, W. A. (2005). Decade of Discourse Analysis of Environmental Politics: Achievements, Challenges, Perspectives. Journal of Environmental Policy \& Planning, 7, 177.

Hall, P. (1993). Policy paradigms, social learning, and the state: the case of economic policymaking in Britain. Comparative Politics, 25(3), 275-296.

Hall, P. A., \& Taylor, R. C. R. (1996). Political Science and the Three New Institutionalisms. Political Studies, 44(5), 936-957.

Harris, L. (2008). Water rich, resource poor: intersections of gender, poverty and vulnerability in newly irrigated areas of south-eastern Turkey. World Development, 36(12), 2643-2662.

Hasman, R., Jan Klerk, W., Schoemaker, M., \& Smits, E. (2013), SimBethel: Designing a serious game on flood risk management and housing/urban development for the most urbanized island of the California Delta, student research project. Delft University of Technology. Retrieved on 15 November, 2013 from http://californiawaterblog.com/2013/11/18/board-game-wakens-delta-islanders-on-flood-risks/.

Heikkila, T., \& Gerlak, A. K. (2013). Building a Conceptual Approach to Collective Learning: Lessons for Public Policy Scholars. Policy Studies Journal, 41(3), 484-511.

Hornidge, A., Ul Hassan, M., \& Mollinga, P. (2009). 'Follow the innovation'-A joint experimentation \& learning approach to transdisciplinary innovation research. Bonn: ZEF.

Huitema, D., \& Meijerink, S. (2009). Understanding and managing water policy transitions: a policy science perspective. In D. Huitema \& S. Meijerink (Eds.), Water policy entrepreneurs: A research companion to water transitions around the globe (pp. 23-37). Cheltenham: Edward Elgar.

Ingram, H. (2013). No universal remedies: design for contexts. Water International, 38(1), 6-11.

Ingram, H., \& Lejano, R. (2009). Transitions: transcending multiple ways of knowing water resources in the United States. In D. Huitema \& S. Meijerink (Eds.), Water policy entrepreneurs: A research companion to water transitions around the globe (pp. 61-79). Cheltenham: Edward Elgar.

International Conference on Water and Environment (ICWE). (1992). The Dublin statement on water and sustainable development.

Jeffrey, P. (2007). Critical perspectives on IWRM theory and practice. A CAIWA conference workshop.

Jeffrey, P., \& Gearey, M. (2006). Integrated Water Resources Management: lost on the road from ambition to realization? Water Science and Technology, 53(1), 1-8.

Jochn-Clausen, T., \& Fugl, J. (2001). Firming up the conceptual basis of Integrated Water Resources Management. International Journal of Water Resources Development, 17(4), 501-511.

Jonker, L. (2002). Integrated water resources management: theory, practice, cases. Physics and Chemistry of the Earth, 27, 719-720.

Kaljonen, M., Varjopuro, R., Giełczewski, M., \& Lital, A. (2012). Seeking policy-relevant knowledge: a comparative study of the contextualisation of participatory scenarios for the Narew River and Lake Peipsi. Environmental Science \& Policy, 15(1), 72-81.

Kidd, S., \& Shaw, D. (2007). Integrated water resource management and institutional integration: realising the potential of spatial planning in England. The Geographical Journal, 17(4), 312-329.

Lach, D., Ingram, H., \& Rayner, S. (2005). Maintaining the status quo: How Institutional norms and practices create conservative water organizations. Texas Law Review, 83, 2027-2053.

Lejano, R., \& Ingram, H. (2009). Collaborative networks and new ways of knowing. Environmental Science \& Policy, 12, 653-662.

Lejano, R., Ingram, M., \& Ingram, H. (2013). The power of narratives in environmental networks. Cambridge, MA: MIT Press.

Lejano, R., \& Leong, C. (2012). A Hermeneutic Approach to Explaining and Understanding Public Controversies. Journal of Public Administration Research and Theory, 22, 793-814.

Lemaire, O., Moneyron, A., \& Masson, J. (2010). Interactive Technology Assessment and Beyond: the Field Trial of Genetically Modified Grapevines at INRA-Colmar. PLoS Biology, 8(11), e1000551. 
Lendvai, N., \& Stubbs, P. (2009). Assemblages, Translation, and Intermediaries in South-East Europe. Policy Reconsidered: Meaning, Politics and Practices. In S. Hodgson \& Z. Irving (Eds.). Bristol, UK: Bristol Policy Press.

Lenton, R., \& Muller, M. (2009). Integrated water resources management in practice: Better management for development. London: Earthscan.

Leventon, J., \& Antypas, A. (2012). Multi-level Governance, Multi-level Deficits: The Case of Drinking Water Management in Hungary. Environmental Policy and Governance, 22(4), 253-267.

Levi-Strauss, C. (1966). The savage mind. Chicago: University of Chicago Press.

McCulloch, C. (2009). The Water Resources Board: England and Wales' Venture into National Water Resources Planning, 1964-1973. Water Alternatives, 2, 461-475.

Medema, W. (2006). IWRM and adaptive management: Synergy or conflict, Newater Project.

Medema, W., McIntosh, B., \& Jeffrey, P. (2008). From premise to practice: A critical assessment of integrated water resources management and adaptive management approaches in the water sector. Ecology and Society, 13(2), 29.

Mitchell, B. (1997). Resource and environmental management. Harlow: Addison Wesley Longman.

Mitchell, B. (2005). Integrated water resources management, institutional arrangements, and land-use planning. Environment and Planning A, 37, 1335-1352.

Mitchell, B. (2008). Resource and environmental management: Connecting the academy with practice. Canadian Geographer, 52, 131-145.

Molle, F. (2009). River-basin Planning and Management: The Social Life of a Concept. Geoforum, 40(3), 484-494.

Molle, F. (2011). Implementing integrated river basin management in the red river basin, Vietnam: A solution looking for a problem? Water Policy, 13, 518-534.

Mollinga, P., Dixit, A., \& Athukorala, K. (2006). Integrated water resources management global theory, emerging practice, and local needs. New Delhi: Sage.

Moss, T. (2010). Intermediaries and the Governance of Urban Infrastructures in Transition. In S. Guy, S. Marvin, W. Medd, \& T. Moss (Eds.), Shaping urban infrastructures intermediaries and the governance of socio-technical networks (pp. 17-35). London: Earthscan.

Mukhtarov, F. (2008). Intellectual History and Current Status of Integrated Water Resources Management: a Global Perspective. In C. Pahl-Wostl, P. Kabat, \& J. Möltgen (Eds.), Adaptive and integrated water management: Coping with complexity and uncertainty. Heidelberg: Springer.

Mukhtarov, F. (2009). The hegemony of integrated water resources management: A study of policy translation in England, Turkey and Kazakhstan. Budapest: Department of Environmental Sciences and Policy, Central European University.

Mukhtarov, F. (2012). Rethinking the travel of ideas: Policy translation in the water sector. Policy \& Politics. doi:10.1332/030557312X655459.

Mukhtarov, F., \& Gerlak, A. (2013). River basin organizations in the global water discourse: An exploration of agency and strategy. Global Governance, 19(2), 301-326.

Öktem, K. (2005). Reconstructing the geographies of nationalism: Nation, space and discourse in twentieth century Turkey. Doctor of Philosophy thesis, The Approach of Geography and Environment. Oxford: University of Oxford.

Osseweijer, P. (2006). A short history of talking biotech: Fifteen years of iterative action research in institutionalizing scientists' engagement in public communication. Earth and life sciences. Amsterdam: Vrije Universiteit Amsterdam.

Pahl-Wostl, C., Gupta, J., \& Petry, D. (2008). Governance and the global water system: A theoretical exploration. Global Governance, 14(4), 419-435.

Petit, O., \& Baron, C. (2009). Integrated water resources management: From general principles to its implementation by the state. The case of Burkina Faso. Natural Resources Forum, 33, 49-59.

Rahaman, M., \& Varis, O. (2005). IWRM: evolution, prospects and future challenges. Sustainability: Science, Practice, and Policy, 1(1), 15-21.

Renn, O., Webler, T., Rakel, H., Daniel, P., \& Johnson, B. (1993). Public participation in decision making: a three-step procedure. Policy Sciences, 26(2), 189-214.

Saravanan, V., McDonald, T., \& Mollinga, P. (2009). Critical review of Integrated Water Resources Management: Moving beyond polarised discourse. Natural Resources Forum, 33, 76-86.

Schneider, A., \& Ingram, H. (2007). Ways of knowing: Implications for public policy. Annual meeting of the American Political Science Association, Chicago.

Scott, J. (1998). Seeing like a state: How certain schemes to improve the human conditions have failed. Newhaven, CT: Yale University Press.

Scott, C. A., Varady, R. G., Meza, F., Montaña, E., de Raga, G. B., Luckman, B., et al. (2012). SciencePolicy Dialogues for Water Security: Addressing Vulnerability and Adaptation to Global Change in the Arid Americas. Environment: Science and Policy for Sustainable Development, 54(3), 30-42. 
Smith, N. (1997). Review essay: Reason after meaning: Charles Taylor, Philosophical Arguments. Cambridge, MA: Harvard University Press, 1995). Philosophy Social Criticism, 23, 131-140.

Susskind, L., Camacho, A. E., \& Schenk, T. (2010). Collaborative Planning and Adaptive Management in Glen Canyon: A Cautionary Tale. Columbia Journal of Environmental Law, 35, 1-54.

Tenbensel, T. (2006). Policy knowledge for policy work. In H. Colebatch (Ed.), The work of policy: An international survey (pp. 199-215). Lanham: Rowman and Littlefield.

Tremblay, H. (2011). A clash of paradigms in the water sector? Tensions and synergies between integrated water resources management and the human rights-based approach to development. Natural Resources Journal, 51, 307-356.

United Nations Environmental Programme (UNEP). (1994). Agenda 21: Programme of action for sustainable development: Rio declaration on environment and development. New York: United Nations Environmental Programme.

United Nations Water (UN-Water). (2008). Status report on integrated water resources management and water efficiency plans. New York: The Commission on Sustainable Development.

United Nations Water (UN-Water). (2012). The UN-water status report on the application of integrated approaches to water resource management. Stockholm: UNEP, UNDP, GWP.

United Nations Water (UN-Water). (2013). Theatre of the absurd: Is there a happy ending to the tragedy (of the commons)? Retrieved on 15 November, 2013 from http://www.unwater.org/water-cooperation2013/events/theater-of-the-absurd/en/, Geneva, UN-Water.

van Kerkhoff, L. (2013). Integrated research: concepts of connection in environmental science and policy. Environmental Science \& Policy, 8(5), 452-463.

Wagenaar, H. (2004). 'Knowing' the rules. Administrative work as practice. Public Administration Review, $64,643-656$.

Wagenaar, H., \& Cook, N. (2003). Understanding policy practices: action, dialectic and deliberation in policy analysis. In M. Hajer \& H. Wagenaar (Eds.), Deliberative policy analysis: Understanding governance in the network society (pp. 139-171). Cambridge: Cambridge University Press.

Walther, P. (1987). Against idealistic beliefs in the problem-solving capacities of integrated resource management. Environmental Management, 11(4), 430-446.

Warner, J. (2006). More Sustainable Participation? Multi-Stakeholder Platforms for Integrated Catchment Management. Water Resources Development, 22(1), 15-35.

Watkins, K. (2006). Human development report. Beyond scarcity: Power, poverty and the global water crisis. New York: United Nations Development Programme.

Weible, C. T., Heikkila, T., de Leon, P., \& Sabatier, P. (2012). Understanding and influencing the policy process. Policy Sciences, 45(1), 1-21.

Wenger, E. (1998). Communities of practice: Learning, meaning and identity. Cambridge: Cambridge University Press.

Westley, F. R., Tjornbo, O., Schultz, L., Olsson, P., Folke, C., Crona, B., \& Bodin, Ö. (2013). A theory of transformative agency in linked social-ecological systems. Ecology and Society, 18(3), 27. http://dx. doi.org/10.5751/ES-05072-180327.

White, G. (1998). Reflections on the 50-year International Search for Integrated Water Management. Water Policy, 1, 21-27.

Wilder, M., \& Howlett, M. (2013). The politics of policy anomalies: Bricolage and the hermeneutics of paradigms, prepared for presentation to the American Political Science Association. Retrieved on November 15, 2013 from. https://www.google.az/?gws_rd=cr\&ei=k36KUs_iH9HJswba6oDACw\#q= The + Politics + of + Policy + Anomalies: + +Bricolage + and + the + Hermeneutics + of + Paradigms $\% 2 \mathrm{C}+$ Prepared+for+Presentation+to+the+American+Political+Science+Association.

Yanow, D. (2009). Ways of knowing: Passionate humility and reflexive practice in research and management. The American Review of Public Administration, 39, 579-601. 